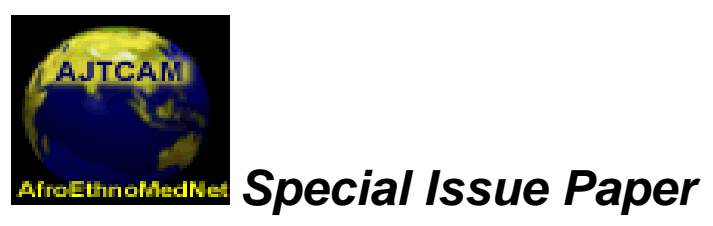

Afr. J. Traditional, Complementary and Alternative Medicines www.africanethnomedicines.net

ISSN 0189-6016@2007

DEVELOPMENT AND POVERTY: A SYMBIOTIC RELATIONSHIP AND ITS IMPLICATION IN AFRICA

\author{
Dokun Oyeshola \\ Department of International Relations, Obafemi Awolowo University \\ Ile-Ife, E-mail: doyeshola@oauife.edu.ng
}

\begin{abstract}
Poverty is present everywhere but the kind in Africa is of great magnitude both in its spread and destitutive dimension. In other places any manifestation of poverty is a challenge to move forward but in Africa, the reverse is the case. Therefore the continent and international community are not happy about it, hence various programmes and strategies were put in place. Ironically there is little to show for it. For instance, about ten years before the end of millennium, the common slogan in Africa was 'water for all, food for all, education for all, health for all and so on by the year 2000'. The 'miracle' year 2000 has come and gone and water, food, education and health are not enjoyed by many citizens of the continent. Development is still illusive. In this paper I examine the issues of poverty and development in the context of deforestation/biodiversity a consequent effect of global warming being one of the major threats to humanity. Some questions are raised with a view to proffer recommendations that may move the continent forward. These are: What are the roots of poverty in Africa? Why should there be a symbiotic relationship between poverty and development in Africa? Can Africa really develop?
\end{abstract}

Key words: Development, sustainable development, poverty, symbiotic relationship, Environment, population

\title{
Introduction
}

Literally it may be affirmed that poverty and development are two sides to a coin; one presupposes and challenges the other. Generally, in the West, it is the manifestation of poverty, constraints, disease or accidents that propels it for progress. This is the story behind inventions and technology. In Africa though, poverty is a hindrance to progress. Lack of infrastructure, deep seated corruption practices, various forms of conflict, bad governance and poor health facilities cannot promote a healthy population committed to work for progress and development. Crudely, every person is unto himself/herself. As pessimistic as this picture may be, all is not lost. Africa can still be a developed continent. It is this belief that motivates the reflection of this discourse.

This paper begins with an analysis of the two principal concepts of development and poverty with special emphasis on what is development and its characteristics, how can development come about, what is poverty and what are the roots of poverty in Africa. This part is followed by the section on relationship between poverty and development using deforestation as a platform for discussion while the last part deals with the question if African countries can really develop.

\section{What is development?}

Development is often assumedly socio-economic, political, science and technology biased. Arguably, the concept of development is a complex one. Its difficulty is not only in terms of definition/description but also in terms of measurement. Is development to be measured by Gross National Product per capital (GNP), by the GDP, or the Physical Quality of Life Index (PQLI)? If GDP were to be the measurement as a mean average, it does not say anything about the distribution of total income of its country. Thus some countries with very unequal income 
distribution may have the higher GNPs per head in the world. And neither does it capture the totality of the development situation of the country. GDP states the value of the economic output as a result of the use of resources mainly of labour, land and capital earned by national members of a society. The outflow (profit and benefits) of multinational enterprises (MNEs) as well as the remittances of immigrants in the society are not included in the calculation. Similarly, the conditions for an effective PQLI may be difficult to establish. Do the usual three indicators of life expectancy, infant mortality at age one and adult literacy discloses everything? Even if the yardstick of democracy, level of corruption and technological advancement is used, does it explain the totality of the concept of development?

The truth is that people are both the means and the end of economic development as rightly affirmed by the international community. 'Human beings are at the center of concerns for sustainable development. They are entitled to a healthy and productive life in harmony with nature' (Principle 1 of Stockholm Conference of 1972). Therefore, development cannot be merely economic development or GNP as important as that may be. It must necessarily include the conditions of reality that allow people to take their destiny into their own hands. Taking their lives into their own hands will involve economic, social, political, psychological, environmental, cultural, religious and international dimensions of their environment. In this wise, development includes the conditions of reality that allow people to take their destiny into their own hands individually and collectively (Oyeshola, 1989). Better still, development can be defined in terms of the ability and capability of a people.

To procure sufficient natural resources to meet the basic needs of all in a self-reliant manner; adjust to adverse environmental changes with minimal disastrous consequences; have a stable, democratic and independent system of government; and maintain harmony within the human community and between human and the rest of the environment (WCC, 2001)

For Mahbub UI Haq, development focus is on human needs, the compilation of poverty profiles, and the situation of the bottom forty percent of society often bypassed by development. He went on further to state that developmental efforts are to be placed on measuring the costs of adjustment not only in terms of lost output, but also in terms of lost lives and the lost human potential (Mahbub Ul Haq, 1989). In this respect, the lesson seems to have been learned by many leaders including some Nigerian leaders that human welfare is the ultimate end of development not GNP figures.

The welfare of the human person, seen in its totality, must interest policy-makers and their executives because the good health of a person becomes his wealth, and his skills cultivated through carefully planned educational programmes and responsible socialisation, provide a crucial factor in production. In this respect, his several endeavours add to the wealth of his nation. Inversely, when health and educational facilities are overstretched as is the case in Nigeria, large numbers of the society remain an asset for goods and services but the rest constitute a chronic liability especially during any hardship the country may experience. In densely populated areas, housing, transportation, sanitation, crimes and the like, pose enormous problems for local, state and other authorities (Tamuno, 1989). For a development planning to be people-centred just as Mahbub Ul Haq (1989) has proposed many years past the following schemes are important. The starting point is a human balance sheet which will include the following information

What human resources exist in the country; how educated they are; what is the inventory of human skills; what is the profile of relative income distribution and absolute poverty; what is the degree of unemployment and under employment; what is the urban-rural distribution and level of human development in various regions; what is the demographic transition; what are the cultural and social forces which motivate people; what is the ideology of the society and what are the aspirations of its people; in other words, how the society actually lives and breathes (Mahbub Ul Haq,1989).

If development strategy is people centred, then community participation must be evident in the process. A project that people/community cannot identify with will eventually collapse. Many of the abandoned 'elephant' projects like Federal Housing Project during the decades of 1970 and 1990 in Nigeria are testimonies. Also development plans must have an inbuilt human framework for analysing and evaluating their performance. A comprehensive set of social and human indicators needs to be developed to monitor plan progress that must necessarily yield to development understood as a dynamism that leads people to self-fulfillment and creative partnership in the use of a nation's productive forces and its full human potential. 
Today the concept of development has taken on a new mask; it is qualified as sustainable development. The term sustainable development was popularized by the World Commission on the Environment and Development (WCED) in 1987 in connection with the use of environmental resources. Before then, a lot of works in contemporary period was already available (Ako, 2005) even though they were not explicit in the usage of the concept of sustainable development. For those who are explicit, herein are some definitions. Sharachchandra Lele describes sustainable development as

a new way of life and approach to social approach to social and economic activities for all societies, rich and poor which is compatible with the preservation of the environment (Lele, 1991)

while Pearce and Watford capture the irreplaceable environmental dimension in sustainable development in the following definition

Sustainable development describes a process in which the natural resource base is not allowed to deteriorate. It emphasizes the hitherto unappreciated role of the environmental quality and environmental inputs in the process of raising real income and quality of life (Pearce and Watford, 1993).

WCED defines sustainable development as 'development that meets the needs of the present without compromising the ability of future generations to meet their own needs' (WCED, 1987). WCED's thesis of sustainable development posits that the present generation has been reckless and wasteful both in its exploitation and use of natural resources by pursuing a series of socio-economic and industrial policies which endangers global environmental security. It urged governments to pursue a new developmental strategy that can both ensure continued economic growth and ecological stability with less exploitation and use of natural resources. It condemned the inequalities with and among nations and called for a restructuring of contemporary economic relations to guarantee an equitable distribution of national and international wealth (Natufe, 2001).

The position of WCED was informed on the basis, among others, that the attempt in the 1970s to create a New International Economic Order (NIEO) based on a Charter of Economic Rights and Duties of the UN did not make reference to and took little account of the impact of development activities on the environment. However, the 1980s strategies, primarily aimed at environmental protection took account of the need for development while recognizing that the environment could not in all cases sustain unlimited development.

Today, the concept of sustainable development is a notion around which legally significant expectations regarding environment conduct have begun to crystallize. The Rio de Janeiro Conference of 1992 and the Johannesburg 2002, 'Earth Summit' promote strategies to fully integrate the relationship between the environment and development. The initiative is a testimony to the currency of sustainable development in global polity.

Sustainable development implies three primary factors of economic, social and environment. An economically sustainable system must be able to produce goods and services on a continuing basis and maintain manageable economy without jeopardizing sectoral balances of economic activities of the country. Environmentally sustainable system must maintain a stable resource base, avoiding over-exploitation of renewable resource systems or environmental sink functions and depleting non-renewable resources only to the extent that investment is made in adequate substitutes. This includes maintenance of biodiversity, atmospheric stability and other ecosystem functions not ordinarily classified as economic resources. The last factor must achieve distributional equity, adequate provision of social services including health and education, gender equity and political accountability, transparency and participation. This must be with dynamic understanding of human rights that is developing very rapidly. Already, there is no argument on the acceptability of rights to life and liberty; they have been recognized while the 'rights' to a healthy environment and development have only developed to a stage of recognition and enforceability under both national and international legal regimes (Ako, 2005: 70). Bearing in mind the social and human-centred development (Stockholm Conference 1972, Principle 1), the definitions of the concept of sustainable development have broken the hitherto 'limited, instrumental view of conservation and development. Now it encompasses some of the positive moral dimensions of the new social paradigm expressed in 'authentic integral development', 'ecological/holistic world view', 'reverential development', 'ecosophical development', 'just, participatory ecodevelopment’, ‘communalism’ and ‘desirable society’(Engel, 1990).

At the end of the day, any development that will be sustaining especially in the developing countries will include the following

* Increases in real income especially for the 'wretched of the earth'. This implies poverty alleviation; 
* Improvements in health and nutritional status especially children and young mothers who are vulnerable to most preventable diseases;

* Education achievement;

* Access to resources;

* A fairer equitable distribution of income. The basic salary of the least paid worker should be adequate to maintain his nuclear family;

* Increases in basic freedoms and guaranteed security of all citizens; respect and responsible relationship with ecosystem.

\section{What is poverty and how can it be eradicated?}

Poverty is not only a lack of money to take care of basic necessity of life it creates a picture of aimlessness, uncertainty and hopelessness at the extreme in the mind of the poor. Where there is no infrastructure and services, people will lack pipe borne water supplies, sewage connections or adequate toilet facilities, garbage collection and basic measures to prevent disease and provide health care. Such deficiencies promote diarrhea, dysenteries, typhoid, intestinal parasites and food poisoning and not development. When combined with malnutrition, these can so weaken the body's defence system and measles, pneumonia and other common childhood diseases become major killers (Cairncross, 1990).

The poor in particular are anxious about the future in regard to the national political life at elections, the degradation of the environment with its devastating consequences, disasters and their destructive effect, the high rise of inequality among people coupled with mass unemployment. There is high level of selfishness in the society with people looking only to their needs and fearful of others. Corruption is endemic. Crime rate is high and the future of generation yet unborn is clouded with uncertainty.

Poverty in Africa is a reality created not only by the internal contradictions like conflict, war, illiteracy, nepotism and corruption within the continent but also and more importantly, by the unequal trade relations between the North and South. Africa lacks the basic requirements necessary to participate effectively and profitably in international trade. It lacks capital and technical expertise.

Foreign debts of African states accrued over a period of time as a result of large-scale borrowing (with nothing to show for it by the way of development) and a dependent form of growth which was virtually built into the postwar International Economic System (IES). Although, a lot of the foreign debt of many African countries has been forgiven, the scar of the wound is yet to heal. In view of the fact that various reforms and World Trade Organisation (WTO) are in place, the African continent does not enjoy fair and equitable share of the IES. The IES is primarily profit orientated. Consequently, everything could be sacrificed on the altar of profit to the detriment of development of peoples and individuals, the often stated corporative responsibility of multinationals towards their overseas constituencies notwithstanding.

Combating poverty through provision of improved basic services enhances rights of participation, entitlements and better income-generation opportunities. These reduce the pressure on local ecosystems. In this context, appropriate frame-work conditions for example, good governance and secured entitlements are key prerequisites here. Global governance requires effective multilateral institutions and the rigorous implementation of international agreements at regional and national level. It also requires good governance in terms of the rule of law, legal certainty for citizens and enterprises, respect for basic human rights, government accountability and anticorruption measures. This enabling environment will help the implementation of national strategies for sustainable development and the national action plans to compact poverty. It will also help to streamline in a consistent and coherent way at national and local level in order to improve the effectiveness and impact of the resources allocation.

Without fundamental economic, social and political reforms and a change of behavior especially on the part of the elite of the South, African efforts to free themselves from the all-pervasive problems of poverty, violence, environmental degradation are bound to fail. In the country, Nigeria must continue to vigorously pursue its reform programmes but this must be done with a human face. It should also promote and address behavioral change and any potential conflicts between the objectives of economic development, poverty reduction and environmental policy. Where there is poverty, there may not be development, yet Africa is an environment of poverty that needs to develop!

\section{Consequences of symbiotic relationship between poverty and development using environmental degradation as a platform}

Environmental degradation in Nigeria manifests in many forms, including the following: deforestation, 
erosion, desertification, improper disposal of domestic and industrial waste and air and water pollution (NEST, 1991). As a result of the degradation there is, among others, a gradual increase in the global temperature leading to global warming which causes flooding with its human and financial implications (Oyeshola, 1995).

Another consequence of environmental degradation leads to intra-personal, interpersonal and communal conflicts. These conflicts arise as a result of undue pressure on the physical environment, degradation, pollution, resource depletion, unfair resource sharing based on conflicting values, differing cultures and national interest, which make people and often neighbours to fight to take position of the leftover of the degradation and inadequate resources. Environmental conflict situations in the Nigerian context include conflicts arising from deforestation leading to erosion, flood, washing away of surface soil of agricultural farmland and by so doing leaving the soil infertile. Other areas are gas flaring and oil spillage with their attendant consequences. Furthermore, desertification, pollution and reckless waste dumping can also be mentioned. Concretely, the consequences of environmental conflict situations are illustrated in the Tiv-jukun crisis, Ogoni-Shell crisis, Chad-Nigeria Border Conflict, Border Conflict between Nigeria and Cameroon and Ife-Modakeke Crisis (Egunjobi, 2005; Oyeshola, 2007) where lives were lost, property destroyed, economic life paralyzed and many citizens becoming 'environmental refuges'.

When the environment is unhealthy due to poverty and resources inadequacy the implication of derivative difficulties arising therefrom, may be devastating, making development almost impossible. In a poor environment, diseases such as tuberculosis, influenza and meningitis are easily transmitted from one person to another. Their spread is often helped by low resistance among inhabitants due to malnutrition. Also, the concentration of smoke necessitated by a combination of open fires, stove and coal or biomass fuels used for cooking and heating contribute to serious respiratory problems especially among women and children. In a poor environment, mosquitoes and tsetse flies are in abundance in many places and they cause diseases. Drinking and using untreated water lead to the spread of diarrhea and other diseases. Malaria and schistosomaiasis are water related. Stagnant waters in gutters and open spaces in residential areas are the usual habitat of mosquitoes whose bites cause malaria. Even a naturally clean water supply in cities and towns may contain an element such as fluoride which can be harmful. Water supply can be contaminated from lead and rusted water pipes that are usually never changed in decades.

An unhealthy or poor population produces less and may be forced into practices damaging to the environment (WHO/UNEP, 1986). The polluted air from industry, transport system and agricultural and domestic chemicals has already damaged many places to the point of causing respiratory problems for many. Many times, it is the poor and the 'wretched of the earth' that are the victims. They have no resources to respond positively to the situation. It is the poor people who suffer most acutely from lack of development. They are often forced to overexploit the natural resources which generally form the basis of their livelihoods. Where there is poverty and people are 'forced' into practices damaging to the environment like cutting down trees for firewood, polluting surrounding waters and so on, development effort will be drastically reduced.

\section{Can African countries really develop?}

The continent does not live in isolation; globalization will not allow it even if it wishes to so live. The programmes and strategies of development enumerated above cannot be pursued in isolation in an attempt to have optimal development. There are a number of international issues that must be confronted. These may include foreign debt reduction/cancellation, fairer terms of trade and non-declining foreign aid. There are also some dilemmas in relation to the concept of development that must be critically ironed out. These are the role of growth as the unquestioned objective of economic policy, techniques for measuring sustainable development, conflicting environmental goals with the philosophy of economic growth, the often divergent interests of politicians and the principles of sustainable development. In addition, is the international platform ready to promote sustainable development for all countries especially in the developing countries? This question is pertinent because sustainable development involves a process of deep and profound change in the political, social, economic, institutional and technological order, including redefinition of relations between developing and more developed counties .

Instruments to combat environmental degradation that are already in existence (Oyeshola, 1998) directly contributes to poverty reduction and promote development, and maintaining the natural environment can help reduce vulnerability to degradation at the same time. This could be accomplished, for instance by encouraging integrated management of water resources, international funding being made available as a priority, in the most water-poor regions where there is a high level of water-borne diseases. Access to clean drinking water should be recognized as a fundamental right under binding international law. In soil protection, salination is a serious problem, so a global monitoring system for the early detection of salination should be established. To reduce indoor and outdoor air pollution, Nigeria could vigorously pursue its biogenic liquefied natural energy supply for easy and accessably 
distributed energy supply across the region. This observation calls for the assistance of global rules and effective international organizations. This means reinforcing international law and intensifying multilateral cooperation. Finally, are the African countries ready to practice democracy and over come corruption to bearest minimum? Can accountability and transparency be found in their political intercourse?

\section{Conclusion}

In the industrialised world any form of deficiency is considered a challenged for progress but in the African countries there is a symbiotic relation between development and poverty. Poverty does not seem to adequately challenge the Africans to embark on the road to industrialization and progress. Poverty is in Africa and without development, citizens may not be able to compete with others because of lack of necessary capital, the technicalknow-how and expertise. Symbiotically, without development poverty may not be eradicated. The solution to the dilemmatic situation in the continent is to confront the reality of poverty and challenges of development simultaneously, nationally and internationally.

\section{References}

1. Ako, R.T. (2005). An Appraisal of the Recognition and Enforcement of Environmental Human Rights for the Sustainable Development of the Niger Delta, An M.Phil Thesis submitted to Obafemi Awolowo University.pp. 56-70.

2. Cairncross, S. el la, (1990). 'The Urban Context' in Cairncross, S., Hardoy, J. E. and Satterthwaite D. (eds), The Poor Die Young: Housing and Health in the Third World, Earthscan, London. Pp.1-24.

3. Engel, J. and Engel. J.G (eds.) (1990). 'Introduction: The Ethics of Sustainable Development', in The Ethics of Environment and Development, University of Arizona Press, Tucson. Pp. 10

4. Egunjobi, L.(1991). 'Nigerian Environmental Conflict Situation: A Review of Selected Cases' in Lele, S.M. 'Sustainable Development: A Critical Review', World Development (19(6): 607-621.

5. Egunjobi, L. (2005). Nigerian Envronmental Conflict Situation: A review of selected cases. In: Albert, I. O. ed. Perspectives on peace and conflict in Africa, Peace ad conflict studies programme, Institute of African Studies, University of Ibadan, in collaboration with John Achers Publishers, Ibadan pp. 272-273.

6. Mahbab Ul Haq, (1989). "People in Development" in The Caracas Report on Alternative Development Indicators, Redefining Wealth and Progress: New Ways to Measure Economic, Social and Environmental Change, The Bootstrap Press, New York. Pp. 18-19

7. Natufe, O. I (2001). 'The Problematic of Sustainable Development and Corporate Social Responsibility: Policy Implications for the Niger Delta'. A Conference Paper delivered at the Second Annual Conference and General Meeting of Urhobo Historical Society, Denville, New Jersey, November 2-4.

8. Nigerian Environmental Action Study Team (NEST) (1991). Nigeria Threatened Environment, Ibadan. P. 45.

9. Oyeshola, D, (1989). The Church and Development in Africa, A Ph.D. Thesis submitted to School of Peace Studies, University of Bradford, Bradford. P. 18

10. Oyeshola, D. (1995). Essentials of Environmental Issues: The World and Nigeria in Perspective, Daily Graphics Publications, Ibadan. Pp. 12-16

11. Oyeshola, D. (1998) Politics of International environmental Regulations, Daily Graphics Publications, Ibadan. Pp. 62-84

12. Oyeshola, D. (2007). 'Environmental Conflict Situations and their resolution in Nigeria: The Role of NGOs and International Organisations' being a paper presented at the Society for peace Studies and Practice Conference, Abuja, 23-25 January, 2007.

13. Pearce, D.W. and Watford. J. J.(1993). World Without End, Washington, D.C. Oxford University Press. P. 8.

14. Tamuno, T, (1989). Nigeria: Its People and Its Problems, The Panel on Nigeria Since Independence History Project, Lagos.

15. World Bank (1987), Environment, Growth and Development. Development Committee Paper 14, World Bank, Washington, DC

16. WCC (2001). Echoes, Justice, Peace and Creation News Programme Unit 111 Publications World Council of Churches, Geneva p. 2.

17. WCED (1987). Our common future, Oxford University Press, Oxford. 